\title{
Is There an Actual Need of Registration? Reflections on Free Formality Principle
}

\author{
Ergysa Ikonomi \\ Law Department, "Ismail Qemali” University, Vlora, Albania \\ Email:ergysa83@yahoo.com
}

How to cite this paper: Ikonomi, E. (2020). Is There an Actual Need of Registration? Reflections on Free Formality Principle. Beijing Law Review, 11, 889-898.

https://doi.org/10.4236/blr.2020.114053

Received: March 12, 2020

Accepted: December 15, 2020

Published: December 18, 2020

Copyright (c) 2020 by author(s) and Scientific Research Publishing Inc. This work is licensed under the Creative Commons Attribution International License (CC BY 4.0).

http://creativecommons.org/licenses/by/4.0/

\begin{abstract}
Free Formality Principle, as a fundamental principle of Berne Convention, since its introduction has been a commodity for the protection of the works of the Union, and same time a strong obstacle for other countries to join the Convention, because of their strict and mandatory registration system. In consideration of changes, digitalization, and all different possibilities of creating, sharing and infringing works, this paper aims to highlight the need of registration of the works. By comparing and analyzing the domestic laws of two countries: Albania and U.S., both part of Berne Convention, the paper will precisely point out the differences not only in their ways of requiring registration of the works, but also in the specific effects they create. The paper will put forth some of the benefits of copyright registration and will try to explain that encouraging registration is actually not a burden, but an opportunity to provide a "healthy situation" with mutual benefits, both for copyright holders and public interest. The paper suggests introducing incentives to the registration system, which can preserve FFP, but also can make copyright holders feel interested to register their works.
\end{abstract}

\section{Keywords}

Free Formality Principle (FFP), Copyright, Voluntary System, Registration, Formalities

\section{Introduction}

Free Formality Principle (FFP) is one of the most liberal approaches on recognizing author's rights. In short words: "the fact of creating a work gives you full rights as its author". FFP is a fundamental principle of Berne Convention, which has reformed national systems of register and protection of works, by establishing the most distinguished feature compared to strictly procedures of registra- 
tion of the objects of Industrial Property. Before Berne Convention there were applied different systems often mandatory, in registering works, as a prerequisite, to easily identifying the author and thus guaranteeing copyright protection. The British Statute of Anne and other national laws that followed it, required as obligatory formalities.

The original text of Berne Convention did not contain FFP (or Principle of Automatic Protection). The principle was introduced by the 1908 Berlin Act of Berne Convention, stating: "The enjoyment and the exercise of these rights shall not be subject to any formality ..." (B.C. Paris Text art. 5/2, 1971). The formalities avoided by Berne Convention were to be understood as conditions required in order to enjoy and exercise copyright, which already were known and applied as: the deposit of a copy of a work: its registration with some public or official body; the payment of registration fees, or one or more of these (WIPO Publications No. 615, 1978). WIPO Copyright Treaty (1996), closely and strongly related to Berne Convention provided by art. 1 and art. 3, in its art. 12 enhanced the idea that enjoying the rights is ensured only when the Contracting Parties provide adequate and effective legal remedies, referred specifically to "rights management information", without aiming to rely on this provision to devise or implement rights management systems that would have the effect of imposing formalities which are not permitted under the Berne Convention (WIPO Publications No. 226).

As one of the most ratified conventions, the Berne Convention directs national laws worldwide to provide for registration formalities only when the authors and other subjects want to exploit the recognized rights through agreements. So, member countries may prescribe model contracts governing the conditions of the utilization of works without this being considered a formality (WIPO Publications No. 615, 1978). The automatic protection to copyright has become universal rule.

The first part of the paper will explain the way the Albanian copyright law has defined its register system of works and agreements on exploiting rights and the way this system works to facilitate and encourage registration.

The second part of the paper will try to give a somewhat different example of U.S. concerning their copyright registration system, thus explaining if there has been any legislative change after U.S. ratified Berne Convention.

The third part of the paper will show some reflections if there is any actual need of registration of the works, by highlighting the benefits of authors, right holders, publishers, researchers, memory institutions and public by using the register/deposit system.

\section{The Albanian No Formalities System}

The work and not its registration, makes you owner of its copyright: "The author's right belongs, by nature, to the natural person who created the work" (Albanian Law art. 3/1, 2016). Albania is part of the Berne Convention 1886, 
since 1993. The Albanian Law on author's rights provides for the automatic protection of works: "For the existence and enforcement of author's right, no registration of the work, or other formalities, is required" (Albanian Law art. 17, 2016). The same is provided by law for the protection of neighboring rights (Albanian Law art. 104, 2016).

In complete accordance with FFP of Berne Convention, Albanian law provides for a voluntary system, which ensures that: "First and foremost, protection may not be made conditional on the observance of any formality whatsoever" (WIPO Publications No. 615, 1978). This system and the way it works, fully reflects the lack of certain formalities imposed to copyright holders. FFP, recognized by Berne Convention doesn't forbid that the national laws provide for formalities applicable to domestic authors, only that outside the country of origin, a Union author may demand protection throughout Union countries free of the need to comply with any formality there, and even without being obliged to prove compliance with any formalities demanded in the country of origin of his work (WIPO Publications No. 615, 1978). The Albanian law on author's right provides for the same standard, and as it cannot impose formalities for foreign works, it does not require any formalities for domestic works, too.

The central copyright register system is designated to guarantee the service of registration (and other services) when and if required from authors. The application can be filed in paper or online, or both and the Albanian Directory of Author's Rights (DDA) keeps and updates the specific register (Albanian Law art. 18/1, 2016).

Furthermore, the law itself provides and advantage to works voluntarily registered the way the law requires. The registration has legal effects by being considered proof of authorship, until proven otherwise by court decision. It is a legal presumption, that the person listed in the register is the author/copyright holder of the registered work.

The specific procedure of registration and the register is managed by DDA and is regulated on the basis of Decisions of Council of Ministers. The register is organized in administrative classes and indexed based on the purpose and application to DDA (DACM No. $34 \mathrm{sec} .16,2017)$. The application form, the declaration of authorship, an identification document, the document that verifies the payment of the fee and a copy of the work are required form the applicant. So, the system is designed to register/deposit of content protected by copyright and related rights; the information on the type of content is supplied by the user (EUIPO, 2018a). DDA reserves the right to request any other document, necessary in verifying the rights, such as a document that proves the inheritance rights. The fees are approved and vary from 2000 lek to 5000 lek (DACM No. 33 Appendix 1, 2017).

From the moment of application, the procedure of registration takes maximally 45 days, 30 days of which are used for the examination of the application. The best part of the time has been left to the examination of the application. It is 
certain that this examination differs from the examination required by law for the registration of the objects of Industrial Property, because it is not a substantial examination. The examination implies the control over the application form, or the deposit of the copy of the work. The examination is needed, to properly evaluate the creation. Not every creation constitutes a copyrighted work. The Albanian law determines a non-exhaustive list of what is legally considered work, and then a list of the creations which are excluded from copyright.

DDA issues a certificate for every successful application. The certificate contains data, made available by the application form, the number, and the date of registration, which is the date when the fee is paid, and application is filed. The certificate proves the registration, but not the authorship (DACM No. 34 sec. 14, $16,17,2017)$.

The Albanian law requires that the agreements of exploiting rights of works must be deposited and registered in the register managed by DDA, such as: publishing agreements, agreements on theatrical and/or musical performances and agreements on transferring exclusively economic rights. Only after the registration the terms of agreements can take effect. FFP, as recognized by Berne Convention, does not imply the absence of formalities on various possible ways of exploiting the rights given by the law (WIPO Publications No. 615, 1978).

\section{U.S. Case on "Required" Copyright Formalities}

The differences in national laws made it difficult to properly apply them in those cases where "foreign elements" were involved, and extremely difficult when it came to seek protection for works outside the country of origin, taking in consideration the variety of ways a work might be presented away from its country of origin. To achieve an international level of protection of works, because of hard work of great minds, was introduced Berne Convention. Its original provisions and further revisions of them, were not worldwide accepted.

The other bloc of states, where stood out U.S. and former Soviet Union, strangely sharing same ideas on copyright at the top of antagonism dictated by the Cold War, didn't become part of Berne Convention, thus creating as an alternative, in 1952 the Universal Copyright Convention (U.C.C.). The Europe-centered Berne Convention and its provisions on moral rights, the principle of "no formalities" and the minimum duration of 50 years after the author's death were some of the obstacles (Von Lewinski, 2006), which impeded the U.C.C. countries to accept Berne Convention. Although U.C.C. its flexibility, it cannot be denied the decreasing of its importance through the years; first the collapse of Soviet Union and its independent republics became part of Berne Convention and second U.S. became part of Berne Convention in 1989. One of the most distinguished elements, inherited from U.C.C. was the symbol $\odot$, which became part of legal formalities on copyright.

U.S. resisted 102 years to Berne Convention, gradually approached it by reforming its Copyright Law. The U.S. Copyright Office (USCO, 2020) offers dif- 
ferent possibilities of copyright registration depending to the genre of work. There are basic registration and group registration; paper registration and online registration; renewal registration (USCO, 2020), supplementary registration and other registrations. The fees vary from $\$ 25$ to $\$ 400$ (USCO, 2020). An application contains three essential elements: 1) completed application form, 2) a nonrefundable filing fee, and 3) a nonreturnable deposit of copies of the work being registered and "deposited" with the USCO (USCO, 2019). All applications submitted for registration shall include a certification (USCO, 2019). The declaration shall state that the information provided within the application is correct to the best of the certifying party's knowledge (USCFR, title 37, part 202.3).

The Artists' Rights and Theft Prevention Act of 2005 presented preregistration, which in fact does not constitute a proper or a form of registration. A work eligible for preregistration may be preregistered by submitting an application and fee to the USCO, if is: 1) unpublished; 2) being prepared for commercial distribution; and 3) in a class of works that the Register of Copyrights has determined has had a history of infringement prior to authorized commercial release (USCFR, title 37, part 202.16). Preregistration is considered an indication to the intent of publishing later the work. The applicant, not later than 3 months after the first publication of a work preregistered, shall submit to the Copyright Office an application for registration of the work (USART Act sec. 104, 2005).

According to U.S. Copyright Law, there is no need to formalities to own "copyright" of the work. You own it because you create it. Since March 1, 1989, it is not required any more the application of a copyright notice, which consisted of the copyright symbol or the word "Copyright," the name of the copyright owner, and the year of first publication (USCO, 2019). The copyright notice and the copyright symbol because the U.S. Berne Convention Implementation Act of 1988 was enacted, were devalued. Although, a copyright notice on a work cannot replace its registration. There are even some myths like the poor man's doctrine about alternatives to registration. These alternatives do not have any legal value and cannot replace the registration provided by law.

Registration of the works is not mandatory. The fact of having the work registered is not enough to prove authorship, but it is something that legally can put you in an advantageous position in court, in case of a legal dispute over a copyright infringement.

First, for US works, before filing a suit for infringement, the work has to be registered. This is not only important, but also a sine qua non condition to meet, to claim rights in court. Second, when registration is made before or within five years of publication, the facts stated in the certificate constitute a prima facia evidence in court (USCA sec, $410 \mathrm{c}, 1976$ ). Thus, the registration is more than sufficient to presume the authorship, unless rebutted. Third, besides of its value, if registration is made prior to infringement or within three months after publication of the work, the copyright owner can claim even statutory damages, attorneys' fees, and other costs. So, the moment of registration is also important. It 
is called "timely registration", which helps the copyright owner to recover more money in case of an infringement. Fourth, the copyright owner of a registered work may easily prevent the importation of infringing copies, by establishing a record with the U.S. Customs and Border Protection (USCO, 2019).

In 2019 the case Fourth Estate Public Benefit Corp. v. Wall-Street.com, LLC, et al., showed the importance of registration as a sine qua non condition to preexist before a copyright claimant may commence an infringement suit. Even the petitioner Fourth Estate Public Benefit Corporation had already filed applications to register the articles which the respondent Wall-Street.com, LLC failed to remove from its website after canceling the parties' license agreement, but USCO had not acted on those applications (Fourth Estate Public Benefit Corp. v. Wall-Street.com LLC, et al., 2019).

The debate was over the fact that which moment has to be considered as: "registration of the copyright claim has been made" 1) the moment the claimant files for application, pay the fee and deposit the copies or 2) the moment USCO registers the copyright. The U.S. Supreme Court, in accord with the United States Court of Appeals for the Eleventh Circuit, stated that only upon registration of the copyright, however, a copyright owner can recover for infringement that occurred both before and after registration (US Supreme Court, 2019). After the amends, in accordance to Berne Convention, U.S. copyright law demands for domestic copyright owners to register their copyrights, or demonstrate that they attempted to register and were refused before bringing a suit, thus not necessarily the registration must occur before the defendant's infringing activities (Barrett, 2008).

In accordance with what is required by law the U.S. Supreme Court reasoned: "Registration is thus akin to an administrative exhaustion requirement that the owner must satisfy before suing to enforce ownership rights" (US Supreme Court, 2019).

After the long resistance to Berne Convention, U.S. became part of it, while on the way of amending the system, even though the system of protection and registration of copyright preserved some elements, in order to maintain the typical characteristics, such as being favorable to registered works.

\section{Benefits from Copyright Registration}

Mandatory or voluntary, the registration/deposit systems require accurate data applications and deposit of copy/ies as part of "formalities". There are a lot of benefits from registration, deposit and/or copyright notice, such as:

1) informing the others that this work has a copyright owner. Prudent copyright owners usually affix to the copies the copyright symbol and other required information, as an inexpensive means for complying with all formalities in U.C.C, countries and as a practical reason, because the copyright notice serves as a low-cost "No Trespassing" sign (Goldstein, 2001). With no legal value, the symbol @ is widely known and linked to copyright protection, so it can be con- 
sidered an effective measure to remind anyone that it is put on a protected work.

2) the copyright owner and his contact information are available if someone is interested in further exploiting the work. As a market-based reason, the recorded data in the registry, which can be offered at a low cost, also can facilitate trade, as copyright holders can make profits by selling or licensing their works (Oliar, Pattison, \& Powell, 2014). The recorded information and updating it every time there is a transfer of rights, helps keeping track of who the actual right holder is: the author, the publisher, an heir. Accessible ownership information improves the security of title and facilitates the transfer of proprietary which makes for a more efficient marketplace (Gangjee, 2016).

3) significantly reducing the number of orphan works. The increasing number of orphan works came as the result of FFP and it has created a situation of uncertainty. The existence of orphan works, given the growing appetite for the reuse of the content online, impedes it, (Gangjee, 2016) because there is always hesitation from researchers or producers to use them, because they are afraid of the risk for liability for copyright infringement (Ikonomi, 2018). Registration of the works means to dry the largest source of creating orphan works. As a result, it would improve the process of digitization and making works available to the public, by memory institutions, and it would increase the opportunity of the public to know and to culturally benefit from them (Ikonomi, 2018).

4) advantageous legal effect of registration. A registered work is enough to pass the burden to the defendant to prove that the registration is false. The plaintiff is put in an advantageous position because the registration and the issued certificate are considered prima facie evidence.

5) in case of a dispute over the time of creation of an unpublished work, the date of registration can help. If the author/copyright owner faces difficulties in proving infringement over the work, the words or even the "alternative registration methods" are not enough. The registration in the Copyright Office and the deposit of a copy of the wok constitute strong evidence of the date and content of the work. Lately there are introduced alternative registration of copyright by non-governmental organizations, like in the UK that there are a number of private companies, which offer registration and issue certificates, store information for applicants and can verify in court in case of an infringement, the date the work is registered and produce a copy of it. Or there are available specialized registration and deposit schemes, which are established by professional associations/authors' unions. They offer a limited registration only to the types of works which they represent ( $\mathrm{Yu}, 2006)$. Interesting registration systems, managed by public authorities are also Enveloppe Soleau in France and Benelux i-Depot, where no information on the content is supplied by the user (EUIPO, 2018a). Such deposit systems, by providing evidentiary support, feed into ozher regimes which regulate rights over intangibles (EUIPO, 2018b).

6) the registry is valuable as an indicator. The register managed and updated by the national Copyright Office is the most complete and accurate indicator 
of the level of creation in art, science, and literature, and an indicator of the level of the exploitation of copyrights as well. Data collected from the registry offer interesting and statistical information, valuable to study. Thus, registration provide a good window in the use and performance of copyright (Oliar, Pattison, \& Powell, 2014).

7) registration is aligned with public interest. The authenticity and the reliable information regarding the ownership of copyrights, meaning that better quality information regarding ownership is clearly in public interest. The accurate date and accessible information on protected works would enable an exact prediction of the time the work will enter the public domain (Gangjee, 2016), making possible wide use and with less costs of the work.

8) creating the biggest, unique kind of "Noah's Ark" for all genres of works. Through depositing copies, especially digital copies, copyright national offices can automatically create a collection site, a big unique repository.

\section{Conclusion}

Copyrights are valuable. If well managed, they have impacts on authors, right holders, entities, industries, public, by improving the quality of life. Copyrights are a very discussed set of rights and the way they are guaranteed and protected has shown diversity and differences. The successful effort of great minds resulted in Berne Convention, which determined how copyrights are protected and imposed substantial legal changes in national level. The fundamental principles of Berne Convention are also clearly stated by national laws. Although, every copyright national law bears the history, the tradition, and the philosophy, and shows the way copyrights are perceived.

FFP, since its introduction, made possible the broader access to copyrights protection. The automatic protection for foreign copyright holders, also affected the legal approach even to domestic right holders, to free them from the obligation to face registration formalities. There is no need to go back and to try to reimplement a mandatory copyright registration system. Particularly in countries like Albania, where the level of acknowledgement and awareness of copyright values, is low, the national copyright office DDA has to realize information campaigns, and to improve cooperation with artists associations, publishers, media in order to promote copyright registration.

The digital era enables applying a voluntary registration/deposit system which can be easily used. It is time that the registration process can be digitized by offering online services. There are very good examples like Copyright Index, which has been protected works, since 1999. It is available online and it provides an activated copyright account for each applicant. Through this account the applicant can have access to the copyright system to register by entering the details of the copyright and files associated. The copyright is registered and confirmed and after that the applicant receives a certificate via email (Copyright Index, 2020).

In order to achieve a high level of registration, there has to be applied some 
"little incentives", mainly with financial profits, like: halving the approved fees, applied by DDA, if the registration of the work is made within a year from its realization. Also, artist's organizations and associations can include the registration of the works of their members as a legal measure, by introducing it in their statutes. Other incentives may be applied when there are agreements between municipalities and theatres or galleries. In case the works presented for the public are already registered, the municipality can realize its advertising for free in specified public places used for this purpose.

\section{Conflicts of Interest}

The author declares no conflicts of interest regarding the publication of this paper.

\section{References}

Albanian Law No. 35/2016 on Author's Rights and Other Neighboring Rights.

Barrett, M. (2008). Intellectual Property(2nd ed., p. 181). New York: Aspen Publishers. https://books.google.al/books?id=FetCwyUjdFwC\&pg=PA181\&lpg=PA181\&dq=registr ation + of + works + before+berne + convention \&source $=$ bl\&ots $=$ Ah 2 jFKaxmI\&sig $=$ ACfU 3U1um-xJGR1zFlcXV0vR3GwdV62Ufw\&hl=en\&sa=X\&ved=2ahUKEwiGl4LQg-vnAh WUbsAKHdPsB9s4ChDoATAJegQIChAB\#v=onepage $\& q=$ registration\%20of\%20work s\%20before\%20berne $\% 20$ convention \&f=false

Berne Convention for the Protection of Literary and Artistic Works (Paris Text 1971).

Copyright Index (2020). https://copyrightindex.com/how-it-works

Decision of Albanian Council of Ministers (DACM) No. 33/2017.

Decision of Albanian Council of Ministers (DACM) No. 34/2017.

EUIPO (2018a). Feasibilty Analysis for an EU Digital Deposit System (p. 13). https://euipo.europa.eu/tunnel-web/secure/webdav/guest/document library/observato ry/documents/reports/Feasibility Analysis/2018 Feasibility Analysis of Digital Depo sit System en.pdf

EUIPO (2018b). Study on Voluntary Registration and Deposit Systems: United States and China (p. 8).

https://euipo.europa.eu/tunnel-web/secure/webdav/guest/document library/observato ry/documents/reports/Voluntary_Registration/2018 Voluntary Registration en.pdf

Fourth Estate Public Benefit Corp. v. Wall-Street.com, LLC, et al. https://supreme.justia.com/cases/federal/us/586/17-571

Gangjee, D. S. (2016). Copyright Formalities: A Return to Registration? In R. Giblin, \& K. Weatherall (Eds.), What If We Could Reimagine Copyright? (pp. 216-226). Canberra: ANU Press. https://papers.ssrn.com/sol3/papers.cfm?abstract id=2923897 https://doi.org/10.22459/WIWCRC.01.2017.07

Goldstein, P. (2001). International Copyright. Principles, Law and Practice (p. 189). Oxford: Oxford University Press.

https://books.google.al/books?id=zDyKc6JEn1wC\&pg=PA187\&lpg=PA187\&dq=free+f ormality + principle + was + presented + in + Berne + Convention \&source $=$ bl\&ots $=p 4 T h h N B$ sit\&sig=ACfU3U0-yYw8SQBOjlY1heucgwuVjfVNTw\&hl=en\&sa=X\&ved=2ahUKEwix -LDRoO3nAhULAcAKHdHSAksQ6AEwFHoECBMQAQ\#v=onepage\&q=free $\% 20$ for mality $\% 20$ principle $\% 20$ was $\% 20$ presented $\% 20$ in $\% 20$ Berne $\% 20$ Convention \&f=false 
Ikonomi, E. (2018). Orphan Works-Albania and Kosovo: Two Different Legal Frameworks. Book of Proceedings: International Scientific Conference "Consolidation of the State and Euro-Integration Challenges", Pristina, 142.

Oliar, D., Pattison, N., \& Powell, K. R. (2014). Copyright Registration: Who, What, When, Where and Why. Tex, Law Review, 92, 2213-2217. https://papers.ssrn.com/sol3/papers.cfm?abstract id $=2441378$

The U.S. 1976 Copyright Act (USCA).

The U.S. Artists' Rights and Theft Prevention Act (USART).

U.S. Code of Federal Regulations (USCFR).

U.S. Copyright Office (USCO), 2020. https://www.copyright.gov/about/fees.html

U.S. Supreme Court, No. 17-751, March 4, 2019, Fourth Estate Public Benefit Corp. v. Wall-Street.com, $L L C$, et al., 3.

https://www.supremecourt.gov/opinions/18pdf/17-571 e29f.pdf

USCO (2019). Copyright Basics, Circular 1, 4-5. https://www.copyright.gov/circs/circ01.pdf

Von Lewinski, S. (2006). The Role and Future of the Universal Copyright Convention. e-Copyright Bulletin, 1. https://unesdoc.unesco.org/ark:/48223/pf0000262636

WIPO Copyright Treaty (1996).

WIPO Publications (1978). No. 615 (E), Guide to the Berne Convention for the Protection of Literary and Artistic Works, 33.

https://www.wipo.int/edocs/pubdocs/en/copyright/615/wipo pub 615.pdf

WIPO Publications. No. 226 (E), WIPO Copyright Treaty (WCT) (1996) with the Agreed Statements of the Diplomatic Conference That Adopted the Treaty and the Provisions of the Berne Convention (1971) Referred to in the Treaty (p. 14).

https://www.wipo.int/edocs/pubdocs/en/wipo pub 226.pdf

Yu, M. (2006). Copyright Registration System in Selected Places. Information Note, 13. https://www.legco.gov.hk/yr05-06/english/sec/library/0506in35e.pdf 